\title{
Effect of Dietary Magnesium Level on Nephrocalcinosis and Growth in Rats
}

\author{
Seiichi Kasaoka, ${ }^{*}$ Takao KITAno, ${ }^{1}$ Miho HanaI, \\ Makoto FutatsuKa ${ }^{1}$ and Takatoshi EsASHI \\ Division of Applied Food Research, National Institute of Health and Nutrition, \\ Shinjuku-ku, Tokyo 162-8636, Japan \\ ${ }^{1}$ Department of Public Health, Kumamoto University School of Medicine, \\ Kumamoto 860-0811, Japan
}

(Received December 24, 1997)

\begin{abstract}
Summary We studied the extent of kidney calcification by varying dietary levels of $\mathrm{Mg}$, based on pathological examinations and calcium (Ca) and magnesium $(\mathrm{Mg})$ balance tests. AIN-76 diets containing varying levels of $\mathrm{Mg}-0.3(-\mathrm{M}), 1.3(1 / 20 \mathrm{M}), 2.4(1 / 10 \mathrm{M}), 9.2(1 / 5 \mathrm{M}), 19$ (control), $38(2 \mathrm{M}), 102(5 \mathrm{M})$, and $187(10 \mathrm{M}) \mathrm{mmol} / \mathrm{kg}$ diet-were fed to 3 -week-old male Fischer-344 rats for $14 \mathrm{~d}$. Although the magnitude of abnormality was highest in kidney of rats fed the $-\mathrm{M}$ diet, the damage was normalized as the dietary level of $\mathrm{Mg}$ increased, with increasing serum $\mathrm{Mg}$ concentration and urinary excretion of $\mathrm{Mg}$. We found almost no deposition of $\mathrm{Ca}$ in rats fed the $10 \mathrm{M}$ diet. The mechanism by which the high dietary $\mathrm{Mg}$ induces these effects most likely involves a competition between $\mathrm{Mg}$ and $\mathrm{Ca}$ for reabsorption in proximal and/or distal tubules, since these diets increased the urinary excretion of Ca. However, these high $\mathrm{Mg}$ diets decreased food intake and body weight gain compared with the control diet, although these indices were not decreased in rats fed the $2 \mathrm{M}$ diet. The results suggest that a dietary magnesium level approximately twice the normal level effectively reduces kidney calcification while maintaining normal growth in rats.
\end{abstract}

Key Words calcium deposition, magnesium, nephrocalcinosis, pathological examination, rats

For 16 years, the American Institute of Nutrition's Rodent Diet, AIN-76 (1), has been used extensively worldwide. A major problem with this diet, however, is its propensity to produce calcium deposits in rat kidney $(2,3)$, which many studies

* To whom correspondence should be addressed at present address: Azusawa Research Laboratories, Institute for Consumer Healthcare, Yamanouchi Pharmaceutical Co., Ltd., Itabashi-ku, Tokyo 174-8511, Japan. 
have suggested is the result of a low molar ratio of calcium $(\mathrm{Ca})$ to phosphorus (P) (4-6).

Factors besides the $\mathrm{Ca}: \mathrm{P}$ molar ratio are also suspected of contributing to the calcium deposits, including low dietary levels of magnesium $(\mathrm{Mg})(7)$. The mechanism of calcification in the kidney is unclear. One study found that the main cause was a decreasing urinary excretion of $\mathrm{Ca}(8)$, and several others reported that high dietary intakes of $\mathrm{Mg}$ reduced kidney calcification in rats $(9,10)$.

The aim of the present study was to investigate the proliferation of kidney deposits accompanying changes in dietary $\mathrm{Mg}$ levels, based on pathological examinations and $\mathrm{Ca}$ and $\mathrm{Mg}$ balance tests.

\section{MATERIALS AND METHODS}

General treatment of animals. The study was approved by the National Institute of Health and Nutrition Animal Use Committee, and all rats were maintained in accordance with guidelines for the care and use of laboratory animals, National Institute of Health and Nutrition. Three-week-old male Fischer-344 rats were purchased from Charles River Japan (Kanagawa, Japan). They were housed in individual cages with screen bottoms of stainless steel in a room maintained at $23 \pm 1{ }^{\circ} \mathrm{C}$ and lighted from $0800-2000 \mathrm{~h}$. Body weight and food intake were recorded daily in the morning before the diet was replenished.

Experimental diet. For the first $7 \mathrm{~d}$, rats were fed the control (C) diet (shown in Table 1), an AIN-76 diet (1) slightly modified. Nephrocalcinogenic sucrose was

Table 1. Composition of the experimental diets.

\begin{tabular}{|c|c|c|c|c|c|c|c|c|}
\hline & $-\mathrm{M}$ & $1 / 20 \mathrm{M}$ & $1 / 10 \mathrm{M}$ & $1 / 5 \mathrm{M}$ & $\mathrm{C}$ & $2 \mathrm{M}$ & $5 \mathrm{M}$ & $10 \mathrm{M}$ \\
\hline \multicolumn{9}{|c|}{ Ingredients ( $\mathrm{g} / \mathrm{kg}$ diet $)$} \\
\hline \multicolumn{9}{|l|}{$\begin{array}{l}\text { Constant } \\
\text { components }{ }^{1}\end{array}$} \\
\hline \multirow{2}{*}{$\begin{array}{l}\text { Sucrose } \\
\mathrm{CaHPO} \\
\mathrm{MgO}\end{array}$} & 632.300 & 632.258 & 632.217 & 631.885 & \multirow{2}{*}{$\begin{array}{r}631.470 \\
17.700 \\
0.830\end{array}$} & 630.640 & 628.150 & 624.000 \\
\hline & 0 & 0.042 & 0.083 & 0.415 & & 1.660 & 4.150 & 8.300 \\
\hline \multicolumn{9}{|c|}{ Chemical analysis $(\mathrm{mmol} / \mathrm{kg})$} \\
\hline Magnesium (Mg) & 0.3 & 1.3 & 2.4 & 9.2 & 19.0 & 38.6 & 102.4 & 187.4 \\
\hline Calcium $(\mathrm{Ca})$ & 124.6 & 125.4 & 123.5 & 120.8 & 124.1 & 124.4 & 125.0 & 123.8 \\
\hline Phosphorus (P) & 166.2 & 166.7 & 161.6 & 142.8 & 133.7 & 150.7 & 141.8 & 156.8 \\
\hline $\mathrm{Ca} / \mathrm{Mg}$ & 415.0 & 96.4 & 51.4 & 13.1 & 6.5 & 3.2 & 1.2 & 0.6 \\
\hline
\end{tabular}


substituted as a carbohydrate source for corn starch (11). After $7 \mathrm{~d}$, the rats were divided into 8 groups $(n=6)$, based on body weight, and fed the experimental diets for $14 \mathrm{~d}$. The AIN-76 diet was modified to contain varying levels of $\mathrm{Mg}$ with 0.3 , $1.3,2.4,9.2,19,38,102$, and $187 \mathrm{mmol} / \mathrm{kg}$ diet, coded $-\mathrm{M}, 1 / 20 \mathrm{M}, 1 / 10 \mathrm{M}, 1 / 5 \mathrm{M}$, $\mathrm{C}, 2 \mathrm{M}, 5 \mathrm{M}$, and $10 \mathrm{M}$, respectively.

Sample collection and analysis. From day 7 to day 10, urine was collected in beakers containing $10 \mathrm{~mL}$ of $5 \mathrm{~mol} / \mathrm{L} \mathrm{HCl}$, as were feces for mineral determination. However, urine and feces in rats fed the $10 \mathrm{M}$ diet were not used for mineral determination because separation could not be achieved. After $14 \mathrm{~d}$, rats were decapitated, and blood, right kidneys, and femur were collected for the measurement of $\mathrm{Mg}, \mathrm{Ca}$, and $\mathrm{P}$ levels. The blood was centrifuged, and the serum was kept at $-20^{\circ} \mathrm{C}$ until analysis. The left kidney was fixed with $10 \%$ formalin for pathological examination. The right kidney was digested by a method combining acid hydrolysis and dry heat. Briefly, the kidney was digested and dried with analytical grade nitric acid $\left(80-120^{\circ} \mathrm{C}\right)$, and the residue was then heated to $270-300^{\circ} \mathrm{C}$. After cooling to room temperature, the residue was digested and dried with hydrogen peroxide $\left(80-120^{\circ} \mathrm{C}\right)$, then dissolved in $0.5 \mathrm{~mol} / \mathrm{L} \mathrm{HCl}$ for mineral determination. Femur mineral concentration was determined by the method of Calvo et al (12). $\mathrm{Mg}$ and Ca were analyzed by atomic absorption spectrometry (model Spectre AA-40, Varian, Victoria, Australia) with a $2.5 \mathrm{mg} / \mathrm{L}$ final concentration of strontium in the sample. $\mathrm{P}$ concentration was determined by the Gomori method (13). Bovine liver 1577a from the National Institute of Standard and Technology (Maryland, USA) was digested and analyzed along with samples to confirm accuracy.

Pathological examination. Paraffin slices of the formalin-fixed left kidney were stained with hematoxylin-eosin and Von Kossa's stain. The degree of kidney damage and nephrocalcinosis was scored on a scale from - (not detected) to +++ (severe).

Statistical analysis. Statistical differences were determined by ANOVA and then by Duncan's multiple range test (14). The significance of relationships between data was established by linear regression analysis (15). A probability value of $p<0.05$ was considered significant.

\section{RESULTS}

\section{Body weight and food intake}

Final body weight, body weight gain, food intake, and food efficiency were significantly lower in rats fed the $-\mathrm{M}, 1 / 20 \mathrm{M}, 1 / 10 \mathrm{M}$, and $10 \mathrm{M}$ diets than in those fed the control diet (Table 2). Only food intake was significantly lower in rats fed the $5 \mathrm{M}$ diet relative to the control diet. There were no significant differences in any variables among rats fed the $1 / 5 \mathrm{M}, \mathrm{C}$, and $2 \mathrm{M}$ diets.

\section{Mineral balance}

With a concomitant increase in $\mathrm{Mg}$ intake, the amount of $\mathrm{Mg}$ absorbed and fecal and urinary excretions of $\mathrm{Mg}$ also increased (Table 3). Higher intakes of $\mathrm{Mg}$ 
Table 2. Final body weight, body weight gain, and food intake in rats fed the respective diets. $^{1}$

\begin{tabular}{rccccc}
\hline Diet & $\begin{array}{c}\text { Initial } \\
\text { body weight } \\
(\mathrm{g})\end{array}$ & $\begin{array}{c}\text { Final } \\
\text { body weight } \\
(\mathrm{g})\end{array}$ & $\begin{array}{c}\text { Body weight } \\
\text { gain } \\
(\mathrm{g} / 14 \mathrm{~d})\end{array}$ & $\begin{array}{c}\text { Food } \\
\text { intake } \\
(\mathrm{g} / 14 \mathrm{~d})\end{array}$ & $\begin{array}{c}\text { Food } \\
\text { efficiency } \\
(\mathrm{g} / \mathrm{g} \text { diet })\end{array}$ \\
\hline$-\mathrm{M}$ & $61.7 \pm 1.6$ & $80.9 \pm 1.7^{\mathrm{a}}$ & $19.2 \pm 0.3^{\mathrm{a}}$ & $94 \pm 2^{\mathrm{a}}$ & $0.21 \pm 0.003^{\mathrm{a}}$ \\
$1 / 20 \mathrm{M}$ & $61.7 \pm 1.4$ & $86.0 \pm 2.8^{\mathrm{ab}}$ & $24.3 \pm 1.5^{\mathrm{b}}$ & $99 \pm 3^{\mathrm{ab}}$ & $0.25 \pm 0.009^{\mathrm{b}}$ \\
$1 / 10 \mathrm{M}$ & $61.8 \pm 1.2$ & $90.4 \pm 1.2^{\mathrm{b}}$ & $28.5 \pm 0.9^{\mathrm{bc}}$ & $108 \pm 2^{\mathrm{b}}$ & $0.27 \pm 0.008^{\mathrm{bc}}$ \\
$1 / 5 \mathrm{M}$ & $61.7 \pm 1.1$ & $107.9 \pm 4.0^{\mathrm{c}}$ & $46.2 \pm 2.9^{\mathrm{d}}$ & $139 \pm 5^{\mathrm{cd}}$ & $0.33 \pm 0.012^{\mathrm{d}}$ \\
$\mathrm{C}$ & $61.6 \pm 1.0$ & $109.8 \pm 1.7^{\mathrm{c}}$ & $48.1 \pm 1.5^{\mathrm{d}}$ & $144 \pm 3^{\mathrm{d}}$ & $0.34 \pm 0.008^{\mathrm{d}}$ \\
$2 \mathrm{M}$ & $61.7 \pm 1.0$ & $110.5 \pm 1.5^{\mathrm{c}}$ & $48.8 \pm 0.8^{\mathrm{d}}$ & $143 \pm 2^{\mathrm{cd}}$ & $0.34 \pm 0.005^{\mathrm{d}}$ \\
$5 \mathrm{M}$ & $61.7 \pm 0.9$ & $107.6 \pm 2.3^{\mathrm{c}}$ & $45.8 \pm 1.5^{\mathrm{d}}$ & $134 \pm 4^{\mathrm{c}}$ & $0.34 \pm 0.005^{\mathrm{d}}$ \\
$10 \mathrm{M}$ & $61.8 \pm 0.9$ & $91.3 \pm 1.1^{\mathrm{b}}$ & $29.4 \pm 1.7^{\mathrm{c}}$ & $108 \pm 2^{\mathrm{b}}$ & $0.27 \pm 0.015^{\mathrm{c}}$ \\
\hline
\end{tabular}

${ }^{1}$ Data are expressed as the mean \pm SE. Within a column, values not sharing a superscript letter are significantly different from one another $(p<0.05)$. Among the experimental groups, the letter "a" indicates the smallest value with ascending order of "b," "c," and "d."

were associated with a significant increase in urinary $\mathrm{Ca}$ excretion (Table 4). Although $\mathrm{Ca}$ intake was increased by increasing the food intake, the Ca absorption and retention ratio were similar at all dietary $\mathrm{Mg}$ levels tested. However, urinary excretion of $\mathrm{Ca}(Y)$ was significantly increased at higher levels of $\mathrm{Mg}$ intake and urinary excretion of $\mathrm{Mg}(X)(Y=11.878+0.153 X, R=0.632, p<0.0001)$. Although $\mathrm{P}$ intake was increased by increasing the food intake, the amount of $\mathrm{P}$ absorption was similar at all dietary $\mathrm{Mg}$ levels tested (Table 5). Urinary excretion of $\mathrm{P}$ was significantly lowered by increasing $\mathrm{Mg}$ intake in rats fed the $2 \mathrm{M}, 5 \mathrm{M}$, and $10 \mathrm{M}$ diets, compared with the control diet.

\section{Serum mineral concentrations}

A rise in the dietary level of $\mathrm{Mg}$ was accompanied by an increase in the serum $\mathrm{Mg}$ concentration and a decrease in the ratio of $\mathrm{Ca}$ to $\mathrm{Mg}$, although there were no significant differences in serum $\mathrm{Mg}$ concentrations among rats fed the $-\mathrm{M}$, $1 / 20 \mathrm{M}$, and $1 / 10 \mathrm{M}$ diets (Table 6 ). Nor were there any significant differences in serum $\mathrm{Ca}$ and $\mathrm{P}$ concentrations among rats fed the $\mathrm{C}, 2 \mathrm{M}, 5 \mathrm{M}$, and $10 \mathrm{M}$ diets, although serum $\mathrm{Ca}$ concentration was significantly higher in rats fed the $-\mathrm{M}$, $1 / 20 \mathrm{M}$, and $1 / 10 \mathrm{M}$ diets, and serum $\mathrm{P}$ concentration was significantly lower in rats fed the $1 / 20 \mathrm{M}$ and $1 / 10 \mathrm{M}$ diets, compared with the control diet.

\section{Femur weight and femur mineral concentrations}

Femur fat-free dry weights did not differ among rats fed the $1 / 5 \mathrm{M}, \mathrm{C}, 2 \mathrm{M}$, $5 \mathrm{M}$, and $10 \mathrm{M}$ diets (Table 7). A rise in the dietary level of $\mathrm{Mg}$ was accompanied by an increase in the femur $\mathrm{Mg}$ concentration and a decrease in the femur $\mathrm{Ca}$ 


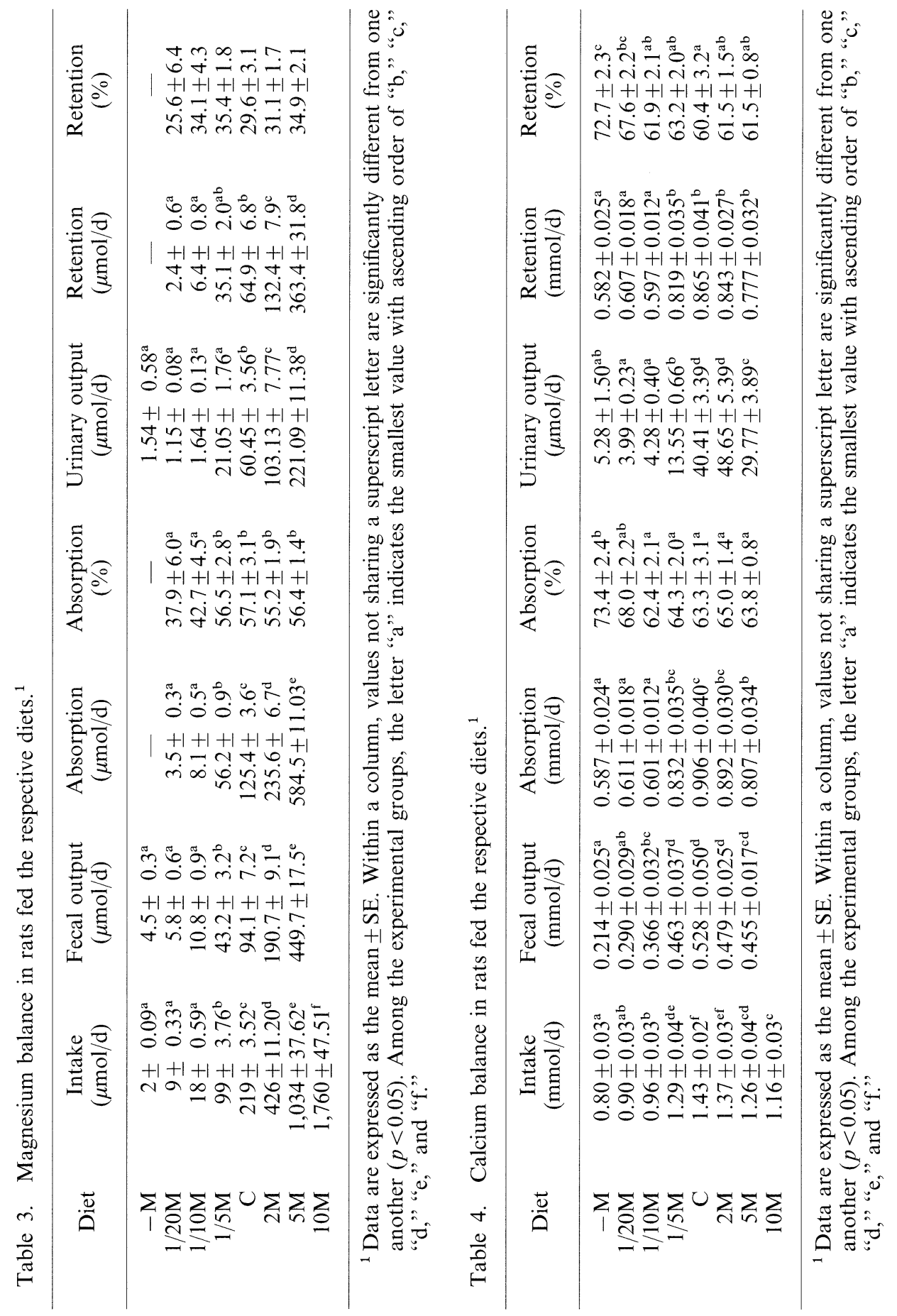




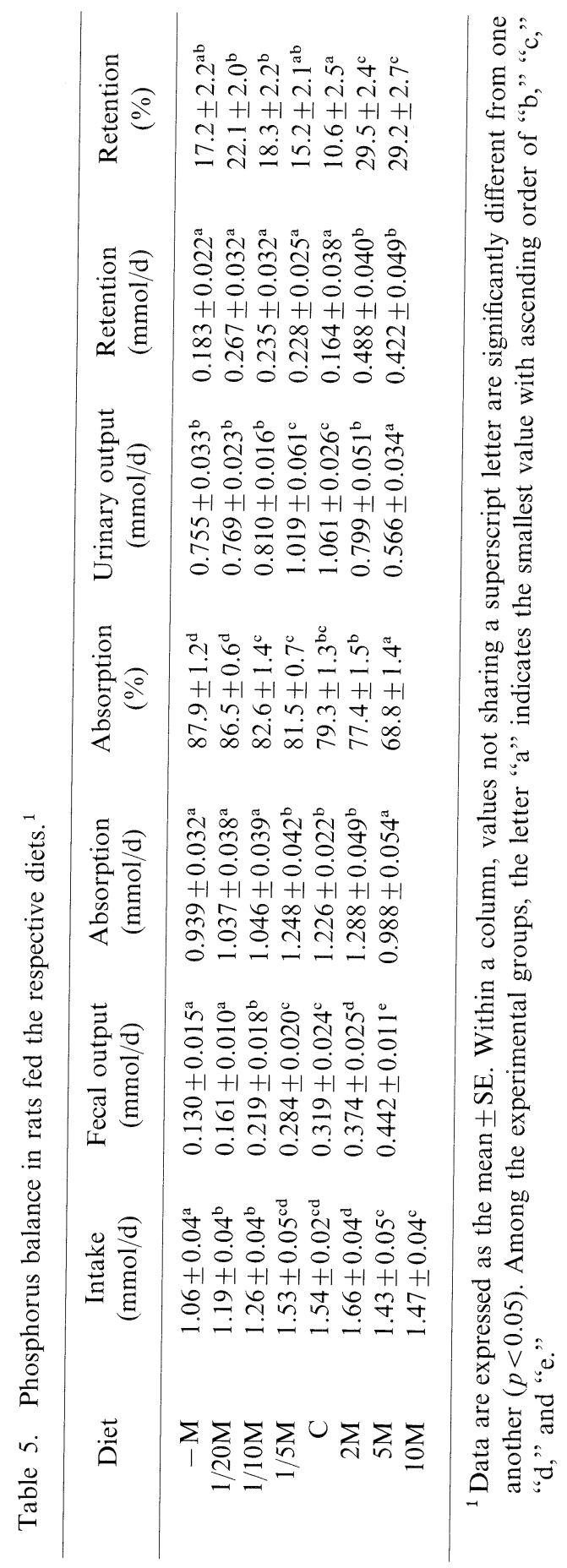


Table 6. Serum magnesium, calcium, and phosphorus concentrations in rats fed the respective diets. ${ }^{1}$

\begin{tabular}{rcccc}
\hline Diet & $\begin{array}{c}\text { Magnesium } \\
(\mathrm{mmol} / \mathrm{L})\end{array}$ & $\begin{array}{c}\text { Calcium } \\
(\mathrm{mmol} / \mathrm{L})\end{array}$ & $\begin{array}{c}\text { Phosphorus } \\
(\mathrm{mmol} / \mathrm{L})\end{array}$ & $\begin{array}{c}\mathrm{Ca} / \mathrm{Mg} \\
(\mathrm{mol} / \mathrm{mol})\end{array}$ \\
\hline$-\mathrm{M}$ & $0.23 \pm 0.01^{\mathrm{a}}$ & $2.91 \pm 0.07^{\mathrm{c}}$ & - & $12.53 \pm 0.28^{\mathrm{d}}$ \\
$1 / 20 \mathrm{M}$ & $0.23 \pm 0.01^{\mathrm{a}}$ & $2.91 \pm 0.03^{\mathrm{c}}$ & $2.45 \pm 0.03^{\mathrm{a}}$ & $12.94 \pm 0.63^{\mathrm{d}}$ \\
$1 / 10 \mathrm{M}$ & $0.22 \pm 0.01^{\mathrm{a}}$ & $2.89 \pm 0.04^{\mathrm{c}}$ & $2.40 \pm 0.06^{\mathrm{a}}$ & $13.21 \pm 0.45^{\mathrm{d}}$ \\
$1 / 5 \mathrm{M}$ & $0.52 \pm 0.01^{\mathrm{b}}$ & $2.73 \pm 0.03^{\mathrm{b}}$ & $2.89 \pm 0.03^{\mathrm{b}}$ & $5.39 \pm 0.15^{\mathrm{c}}$ \\
$\mathrm{C}$ & $0.69 \pm 0.01^{\mathrm{c}}$ & $2.61 \pm 0.04^{\mathrm{ab}}$ & $3.03 \pm 0.05^{\mathrm{bc}}$ & $3.77 \pm 0.06^{\mathrm{b}}$ \\
$2 \mathrm{M}$ & $0.81 \pm 0.004^{\mathrm{d}}$ & $2.54 \pm 0.04^{\mathrm{a}}$ & $2.97 \pm 0.05^{\mathrm{b}}$ & $3.15 \pm 0.06^{\mathrm{ab}}$ \\
$5 \mathrm{M}$ & $0.98 \pm 0.02^{\mathrm{e}}$ & $2.49 \pm 0.08^{\mathrm{a}}$ & $3.14 \pm 0.03^{\mathrm{c}}$ & $2.55 \pm 0.11^{\mathrm{a}}$ \\
$10 \mathrm{M}$ & $1.06 \pm 0.02^{\mathrm{f}}$ & $2.56 \pm 0.02^{\mathrm{a}}$ & $2.99 \pm 0.06^{\mathrm{b}}$ & $2.42 \pm 0.06^{\mathrm{a}}$ \\
\hline
\end{tabular}

${ }^{1}$ Data are expressed as the mean \pm SE. Within a column, values not sharing a superscript letter are significantly different from one another $(p<0.05)$. Among the experimental groups, the letter "a" indicates the smallest value with ascending order of "b," "c," "d," "e," and "f."

Table 7. Femur weight and femur magnesium, calcium, and phosphorus concentrations in rats fed the respective diets. ${ }^{1}$

\begin{tabular}{rccccc}
\hline Diet & $\begin{array}{c}\text { Dry weight } \\
(\mathrm{mg} / 100 \mathrm{~g} \\
\mathrm{BW})\end{array}$ & $\begin{array}{c}\text { Fat-free } \\
\text { dry weight } \\
(\mathrm{mg} / 100 \mathrm{~g} \\
\mathrm{BW})\end{array}$ & $\begin{array}{c}\text { Magnesium } \\
(\mu \mathrm{mol} / \mathrm{g} \text { fat } \\
\text { free femur })\end{array}$ & $\begin{array}{c}\text { Calcium } \\
(\mathrm{mmol} / \mathrm{g} \text { fat free femur })\end{array}$ & $\begin{array}{c}\text { Phosphorus } \\
\text { frem }\end{array}$ \\
\hline$-\mathrm{M}$ & $153 \pm 1.9^{\mathrm{c}}$ & $149 \pm 1.2^{\mathrm{c}}$ & $56.6 \pm 1.3^{\mathrm{a}}$ & $5.38 \pm 0.07^{\mathrm{d}}$ & $2.95 \pm 0.03^{\mathrm{e}}$ \\
$1 / 20 \mathrm{M}$ & $150 \pm 2.4^{\mathrm{c}}$ & $146 \pm 2.5^{\mathrm{c}}$ & $57.7 \pm 1.3^{\mathrm{a}}$ & $5.13 \pm 0.05^{\mathrm{bc}}$ & $2.24 \pm 0.02^{\mathrm{c}}$ \\
$1 / 10 \mathrm{M}$ & $151 \pm 2.2^{\mathrm{c}}$ & $148 \pm 2.4^{\mathrm{c}}$ & $66.7 \pm 2.0^{\mathrm{b}}$ & $5.29 \pm 0.10^{\mathrm{cd}}$ & $2.32 \pm 0.02^{\mathrm{cd}}$ \\
$1 / 5 \mathrm{M}$ & $137 \pm 1.9^{\mathrm{b}}$ & $132 \pm 1.5^{\mathrm{b}}$ & $123.0 \pm 2.3^{\mathrm{c}}$ & $5.18 \pm 0.04^{\mathrm{bc}}$ & $2.37 \pm 0.01^{\mathrm{d}}$ \\
$\mathrm{C}$ & $130 \pm 2.3^{\mathrm{a}}$ & $127 \pm 2.3^{\mathrm{ab}}$ & $155.4 \pm 0.9^{\mathrm{d}}$ & $5.16 \pm 0.03^{\mathrm{bc}}$ & $1.96 \pm 0.06^{\mathrm{b}}$ \\
$2 \mathrm{M}$ & $131 \pm 1.9^{\mathrm{ab}}$ & $128 \pm 2.5^{\mathrm{ab}}$ & $170.4 \pm 1.1^{\mathrm{e}}$ & $5.04 \pm 0.03^{\mathrm{ab}}$ & $2.41 \pm 0.01^{\mathrm{d}}$ \\
$5 \mathrm{M}$ & $130 \pm 2.4^{\mathrm{a}}$ & $127 \pm 2.5^{\mathrm{ab}}$ & $189.7 \pm 0.8^{\mathrm{f}}$ & $4.93 \pm 0.02^{\mathrm{a}}$ & $2.39 \pm 0.01^{\mathrm{d}}$ \\
$10 \mathrm{M}$ & $128 \pm 2.0^{\mathrm{a}}$ & $124 \pm 1.5^{\mathrm{a}}$ & $209.8 \pm 2.4^{\mathrm{g}}$ & $5.02 \pm 0.05^{\mathrm{ab}}$ & $1.59 \pm 0.03^{\mathrm{a}}$ \\
\hline 1
\end{tabular}

${ }^{1}$ Data are expressed as the mean \pm SE. Within a column, values not sharing a superscript letter are significantly different from one another $(p<0.05)$. Among the experimental groups, the letter "a" indicates the smallest value with ascending order of "b," "c," "d," "e," "f," and "g."

concentration, but change was not significant compared with the control diet.

Kidney weight and kidney mineral concentrations

Kidney weight, kidney $\mathrm{Ca}$ and $\mathrm{P}$ concentrations, and the ratio of $\mathrm{Ca}$ to $\mathrm{Mg}$ decreased as the level of $\mathrm{Mg}$ in the diets increased (Table 8). There was a negative 
Table 8. Kidney weight and kidney magnesium, calcium, and phosphorus concentrations in rats fed the respective diets. ${ }^{1}$

\begin{tabular}{rcrrrr}
\hline Diet & $\begin{array}{c}\text { Kidney weight } \\
(\mathrm{mg} / 100 \mathrm{~g} \\
\mathrm{BW})\end{array}$ & $\begin{array}{c}\text { Magnesium } \\
(\mu \mathrm{mol} / \mathrm{g} \\
\text { kidney })\end{array}$ & $\begin{array}{c}\text { Calcium } \\
(\mu \mathrm{mol} / \mathrm{g} \\
\text { kidney })\end{array}$ & $\begin{array}{c}\text { Phosphorus } \\
(\mu \mathrm{mol} / \mathrm{g} \\
\text { kidney })\end{array}$ & $\begin{array}{c}\mathrm{Ca} / \mathrm{Mg} \\
(\mathrm{mol} / \mathrm{mol})\end{array}$ \\
\hline$-\mathrm{M}$ & $967 \pm 13^{\mathrm{d}}$ & $7.2 \pm 0.1^{\mathrm{a}}$ & $213.5 \pm 11.2^{\mathrm{e}}$ & $197 \pm 6^{\mathrm{e}}$ & $29.44 \pm 1.32^{\mathrm{e}}$ \\
$1 / 20 \mathrm{M}$ & $993 \pm 14^{\mathrm{d}}$ & $7.5 \pm 0.1^{\mathrm{a}}$ & $234.5 \pm 12.7^{\mathrm{e}}$ & $208 \pm 8^{\mathrm{e}}$ & $31.30 \pm 1.31^{\mathrm{e}}$ \\
$1 / 10 \mathrm{M}$ & $1,038 \pm 27^{\mathrm{e}}$ & $7.4 \pm 0.2^{\mathrm{a}}$ & $187.5 \pm 12.5^{\mathrm{d}}$ & $179 \pm 7^{\mathrm{d}}$ & $25.34 \pm 0.95^{\mathrm{d}}$ \\
$1 / 5 \mathrm{M}$ & $658 \pm 16^{\mathrm{c}}$ & $10.1 \pm 0.2^{\mathrm{c}}$ & $118.1 \pm 6.6^{\mathrm{c}}$ & $154 \pm 4^{\mathrm{c}}$ & $11.72 \pm 0.52^{\mathrm{c}}$ \\
$\mathrm{C}$ & $542 \pm 18^{\mathrm{b}}$ & $10.7 \pm 0.4^{\mathrm{d}}$ & $89.4 \pm 5.9^{\mathrm{b}}$ & $137 \pm 4^{\mathrm{b}}$ & $8.30 \pm 0.35^{\mathrm{b}}$ \\
$2 \mathrm{M}$ & $510 \pm 4^{\mathrm{a}}$ & $8.4 \pm 0.1^{\mathrm{b}}$ & $17.2 \pm 2.4^{\mathrm{a}}$ & $99 \pm 2^{\mathrm{a}}$ & $2.03 \pm 0.27^{\mathrm{a}}$ \\
$5 \mathrm{M}$ & $492 \pm 7^{\mathrm{a}}$ & $8.2 \pm 0.1^{\mathrm{b}}$ & $1.9 \pm 0.1^{\mathrm{a}}$ & $90 \pm 1^{\mathrm{a}}$ & $0.24 \pm 0.01^{\mathrm{a}}$ \\
$10 \mathrm{M}$ & $528 \pm 7^{\mathrm{a}}$ & $8.4 \pm 0.04^{\mathrm{b}}$ & $1.9 \pm 0.1^{\mathrm{a}}$ & $90 \pm 1^{\mathrm{a}}$ & $0.23 \pm 0.01^{\mathrm{a}}$ \\
\hline
\end{tabular}

${ }^{1}$ Data are expressed as the mean \pm SE. Within a column, values not sharing a superscript letter are significantly different from one another $(p<0.05)$. Among the experimental groups, the letter "a" indicates the smallest value with ascending order of "b," "c," "d," and "e."

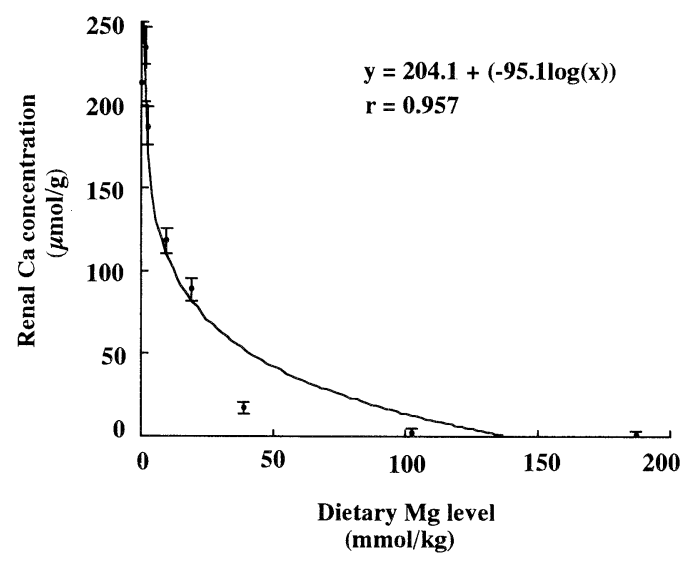

Fig. 1. A logarithmic curve between renal Ca concentration (mean \pm SE) and dietary Mg level.

correlation between kidney $\mathrm{Ca}(Y)$ and serum $\mathrm{Mg}(X)$ concentration ( $Y=$ $267-269 X, R=0.953, p<0.0001$ ), although there were no significant correlations between kidney $\mathrm{Ca}$ and $\mathrm{Mg}$ concentrations. Kidney $\mathrm{Mg}$ was lower in rats fed the $-\mathrm{M}, 1 / 20 \mathrm{M}, 1 / 10 \mathrm{M}, 2 \mathrm{M}, 5 \mathrm{M}$, and $10 \mathrm{M}$ diets than in rats fed the control diet. Figure 1 shows a logarithmic curve between renal $\mathrm{Ca}$ concentration and dietary Mg level. 
Table 9. Pathological findings of kidney in rats fed the respective diets. ${ }^{1}$

\begin{tabular}{|c|c|c|c|c|c|c|c|c|}
\hline \multirow[b]{2}{*}{ Diet } & \multirow{2}{*}{$\begin{array}{l}\text { Deposit of } \\
\text { calcium }\end{array}$} & \multirow{2}{*}{$\begin{array}{c}\text { Glo- } \\
\text { merulus }\end{array}$} & \multirow[b]{2}{*}{ Cortex } & \multicolumn{3}{|c|}{ Medulla } & \multirow{2}{*}{$\begin{array}{c}\text { Cell } \\
\text { Infiltra- } \\
\text { tion }\end{array}$} & \multirow[b]{2}{*}{ Fibrosis } \\
\hline & & & & $\begin{array}{l}\text { Outer } \\
\text { stripe }\end{array}$ & $\begin{array}{l}\text { Inner } \\
\text { stripe }\end{array}$ & $\begin{array}{c}\text { Inner } \\
\text { zone }\end{array}$ & & \\
\hline$-\mathrm{M}$ & $\begin{array}{c}1,200-1,700 \\
(1,401)^{2}\end{array}$ & - & + & +++ & ++ & + & + & \pm \\
\hline $1 / 20 \mathrm{M}$ & $\begin{array}{c}1,150-1,700 \\
(1,409)\end{array}$ & - & + & +++ & ++ & + & + & \pm \\
\hline $1 / 10 \mathrm{M}$ & $\begin{array}{l}950-1,500 \\
(1,228)\end{array}$ & - & + & +++ & + & + & + & \pm \\
\hline $1 / 5 \mathrm{M}$ & $\begin{array}{c}550-750 \\
(607)\end{array}$ & - & - & ++ & + & \pm & \pm & - \\
\hline $\mathrm{C}$ & $\begin{array}{c}200-350 \\
(303)\end{array}$ & - & - & ++ & \pm & \pm & \pm & - \\
\hline $2 \mathrm{M}$ & $\begin{array}{c}60-120 \\
(91)\end{array}$ & - & - & + & \pm & \pm & \pm & - \\
\hline $5 \mathrm{M}$ & $\begin{array}{r}3-10 \\
(5)\end{array}$ & - & - & \pm & - & - & - & - \\
\hline $10 \mathrm{M}$ & $\begin{array}{l}0-2 \\
(1)\end{array}$ & - & - & - & - & - & - & - \\
\hline
\end{tabular}

${ }^{1}-$ : normal.,, \pm+++ , and +++ : magnitude of abnormality $( \pm<+<++<$ +++ ).

${ }^{2}$ Within parentheses, values are expressed as means.

\section{Pathological examination of kidney calcification}

A rise in the dietary level of $\mathrm{Mg}$ was accompanied by a decrease in $\mathrm{Ca}$ deposition and a normalization of pathological indices (Table 9). Moreover, we found almost no deposition of $\mathrm{Ca}$ and no abnormality by pathological examination in rats fed the $10 \mathrm{M}$ diet. Abnormalities in the cortex were found in rats fed the $-\mathrm{M}, 1 / 20 \mathrm{M}$, and $1 / 10 \mathrm{M}$ diets and were associated with increasing kidney weights and kidney and serum Ca levels. Furthermore, abnormalities in the medulla were found in these three groups. Most abnormalities occurred in the outer stripe of medulla, in which proximal and distal tubules are located. Fibrosis was found in rats fed the $-\mathrm{M}, 1 / 20 \mathrm{M}$, and $1 / 10 \mathrm{M}$ diets. Fewer abnormalities of the medulla were present in rats fed the $2 \mathrm{M}, 5 \mathrm{M}$, and $10 \mathrm{M}$ diets than those fed the control diet. Representative sections of kidneys from rats fed the $-\mathrm{M}$, control, and $10 \mathrm{M}$ diets are shown in Fig. 2.

\section{DISCUSSION}

Nephrocalcinosis, induced in rats fed an Mg-deficient diet, is a pathological condition of the kidney in which intratubular calcified deposits occur along the 

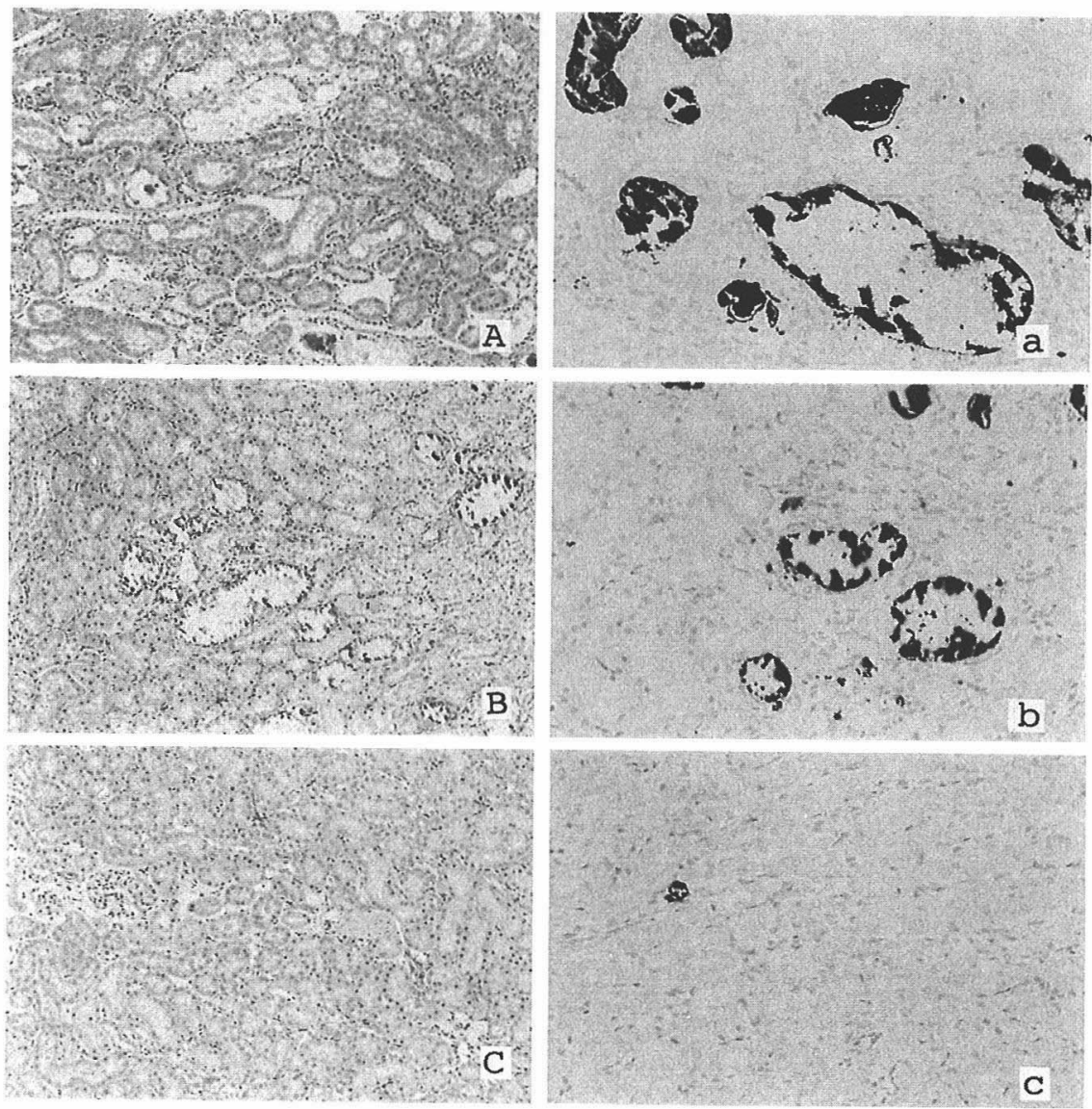

Fig. 2. Typical histopathological appearance of kidney tissue of rats fed the $-\mathrm{M}$, control, and 10M diets. Paraffin slices of the formalin-fixed left kidney were stained with hematoxylin-eosin $(\times 100)$. Photograph $\mathrm{A}$ is from rats fed the $-\mathrm{M}$ diet, B from rats fed the control diet, and $\mathrm{C}$ from rats fed the $10 \mathrm{M}$ diet. Paraffin slices of the formalin-fixed left kidney were stained with Von Kossa's $(\times 100)$. Photograph $\mathrm{a}$ is from rats fed the $-\mathrm{M}$ diet, $\mathrm{b}$ from rats fed the control diet, and $\mathrm{c}$ from rats fed the $10 \mathrm{M}$ diet.

entire corticomedullary junction (16). In the present study, by examining dietary levels of $\mathrm{Mg}$, we found that abnormalities proliferated from the outer stripe in the medulla to the cortex and inner zone in the medulla of kidney as the dietary level of $\mathrm{Mg}$ decreased. Furthermore, we found that urinary excretion of $\mathrm{Ca}$ decreased as the dietary level of $\mathrm{Mg}$ decreased, while the serum $\mathrm{Ca}$ level slightly increased and $\mathrm{Ca}$ absorption slightly decreased, compared with the normal level of $\mathrm{Mg}$. We suggest that increased $\mathrm{Ca}$ reabsorption promotes $\mathrm{Ca}$ deposition in the kidney of rats fed a low $\mathrm{Mg}$ diet.

High dietary intakes of $\mathrm{Mg}$ were associated with reduced kidney calcification 
in rats $(9,10)$. Woodard and Jee (17) reported that renal Ca was linearly decreased in rats fed the $\mathrm{Mg} 82$ and $144 \mathrm{mmol} / \mathrm{kg}$ diets, although they did not prepare an $\mathrm{Mg}$-deficient diet in the study. They suggested singly that renal $\mathrm{Ca}$ deposition was reduced in rats fed the high $\mathrm{Mg}$ diet. In the present study, we prepared different-dose $\mathrm{Mg}$ diets, from 0.3 to $187.4 \mathrm{mmol} / \mathrm{kg}$ diet, and obtained a logarithmic curve between renal $\mathrm{Ca}$ concentration and dietary $\mathrm{Mg}$ level. In particular, renal $\mathrm{Ca}$ concentration was decreased much more in rats fed a dietary $\mathrm{Mg}$ level 2 times higher than the control. We suggest that the $2 \mathrm{M}$ diet effectively reduced $\mathrm{Ca}$ deposition of kidney. Cruikshank et al (18) and Rude and Singer (19) reported that Mg competed with $\mathrm{Ca}$ for tubular reabsorption. Pastoor et al (8) speculated that increased amounts of renal-filtered $\mathrm{Mg}$ depress reabsorption of $\mathrm{Ca}$ and increase the urinary excretion of $\mathrm{Ca}$. In the present study, a rise in the dietary level of $\mathrm{Mg}$ was accompanied by an increase in the serum $\mathrm{Mg}$ concentration. We suggest that nephrocalcinosis is reduced at high dietary $\mathrm{Mg}$ levels because of an effect on the reabsorption of $\mathrm{Mg}$ and $\mathrm{Ca}$ in the proximal and/or distal tubules.

Ritskes-Hoitinga and Beynen (16) reported that a low $\mathrm{Mg}$ diet reduces food intake in rats. However, it is not to be emphasized that food intake is also changed in rats fed a high $\mathrm{Mg}$ diet. In the present study, food intake was reduced in rats fed the low $\mathrm{Mg}$ diet, and also the $10 \mathrm{M}$ and $5 \mathrm{M}$ diets, but the $2 \mathrm{M}$ diet did not reduce food intake. Siu et al (20) focused on feedback regulation of $\mathrm{P}$ intake and reported that food intake was mediated by the mineral content in diet, and that the mechanism most likely involved plasma Ca homeostasis. In the present study, serum $\mathrm{Ca}$ levels were regulated in a narrow range. We speculate that a feedback mechanism exists by which rats regulate their $\mathrm{Ca}$ intake.

We consider that an extremely high $\mathrm{Mg}$ diet is not suitable for elucidating the mechanism of $\mathrm{Ca}$ deposition in normal rats because food intake is reduced, although a diet high in $\mathrm{Mg}$ clearly reduces $\mathrm{Ca}$ deposition. However, the $2 \mathrm{M}$ diet did not reduce food intake, body weight gain, or femur $\mathrm{Ca}$ concentrations, although $\mathrm{Ca}$ deposition in the kidney of rats fed the $2 \mathrm{M}$ diet was a third that of rats fed the control diet. Furthermore, abnormalities in the medulla of kidney were normalized in rats fed the $2 \mathrm{M}$ diet.

We suggest that a dietary $\mathrm{Mg}$ level 2 times higher than the currently recommended level would effectively reduce kidney calcification in rats while maintaining normal growth.

\section{REFERENCES}

1) American Institute of Nutrition. 1977. Report of the American Institute of Nutrition ad hoc committee on standards for nutritional studies. J Nutr 107: 1340-1348.

2) Hoek AC, Lemmens AG, Mullink JWMA, Beynen AC. 1988. Influence of dietary calcium: phosphorus ratio on mineral excretion and nephrocalcinosis in female rats. $J$ Nutr 118: 1210-1216.

3) Mars YWHM, Lemmens AG, Beynen AC. 1988. Dietary phosphorus and nephrocalcinosis in female rats. Nutr Rep Int 38(2): 249-258. 
4) Adams C, Ritskes-Hoitinga J, Lemmens AG, Beynen AC. 1989. Dietary restriction of phosphorus and nephrocalcinosis in two inbred strains of rats. Nutr Rep Int 42: 923929.

5) Shah BG, Belonje B. 1991. Different dietary calcium levels required to prevent nephrocalcinosis in male and female rats. Nutr Res 11: 385-390.

6) Shah BG, Trick KD, Belonje B. 1986. Factors affecting nephrocalcinosis in male and female rats fed AIN-76 salt mixture. Nutr Res 6: 559-570.

7) Esashi T, Hanai M. 1993. Bioavailability of magnesium contained in purple laver (Asakusa-Nori) by rats with scarce magnesium, being evaluated from serum magnesium, kidney calcification, and bone magnesium contents. J Nutr Sci Vitaminol 39: 381-387.

8) Pastoor FJH, Klooster ATV, Opitz R, Beynen AC. 1995. Effect of dietary magnesium level on urinary and faecal excretion of calcium, magnesium and phosphorus in adult, ovariectomized cats. Br J Nutr 74: 77-84.

9) Goulding A, Malthus RS. 1969. Effect of dietary magnesium on the development of nephrocalcinosis in rats. $J$ Nutr 97: 353-358.

10) Harwood EJ. 1982. The influence of dietary magnesium on reduction of nephrocalcinosis in rats fed purified diet. Lab Anim 16: 314-318.

11) Kang SS, Price RG, Yudkin J, Worcester NA, Bruckdorfer KR. 1979. The influence of dietary carbohydrate and fat on kidney calcification and the urinary excretion of $\mathrm{N}$-acetyl- $\beta$-glucosaminidase (EC 3.2.1.30). Br J Nutr 41: 65-71.

12) Calvo MS, Bell RR, Forbes M. 1982. Effect of protein-induced calciuria on calcium metabolism and bone status in adult rats. J Nutr 112: 1401-1413.

13) Gomori G. 1942. A modification of the colorimetric phosphorus determination for use with the photoelectric colorimeter. J Lab Clin Med 27: 955-962.

14) Shibata K. 1974. Basic Statistics for Biologist (in Japanese), p 64-78. Shobun Publishing, Tokyo.

15) Snedecor GW, Cochran WG. 1967. Statistical Methods, 6th ed, p 166-190. Iowa State University Press, Ames, IA.

16) Ritskes-Hoitinga J, Beynen AC. 1992. Nephrocalcinosis in the rat: a literature review. Prog Food Nutr Sci 16: 85-124.

17) Woodard JC, Jee WSS. 1984. Effects of dietary calcium, phosphorus and magnesium on intranephronic calculosis in rats. J Nutr 114: 2331-2338.

18) Cruikshank DP, Pitkin RM, Donnelly E, Reynolds A. 1981. Urinary magnesium, calcium, and phosphate excretion during magnesium sulfate infusion. Obstet Gynecol 58: $430-434$.

19) Rude RK, Singer FR. 1981. Magnesium deficiency and excess. Ann Rev Med 32: 245 259.

20) Siu GM, Hadley M, Draper HH. 1981. Self-regulation of phosphate intake by growing rats. $J$ Nutr 111: 1681-1685. 